\title{
Ligands specify estrogen receptor alpha nuclear localization and degradation
}

Silvia Kocanova ${ }^{1,2+}$, Mahta Mazaheri ${ }^{1,2+}$, Stéphanie Caze-Subra ${ }^{1,2}$, Kerstin Bystricky ${ }^{1,2^{*}}$

\begin{abstract}
Background: The estrogen receptor alpha (ER $\alpha$ ) is found predominately in the nucleus, both in hormone stimulated and untreated cells. Intracellular distribution of the ER $\alpha$ changes in the presence of agonists but the impact of different antiestrogens on the fate of ER $\alpha$ is a matter of debate.

Results: A MCF-7 cell line stably expressing GFP-tagged human ER $\alpha$ (SK19 cell line) was created to examine the localization of ligand-bound GFP-ER $\alpha$. We combined digitonin-based cell fractionation analyses with fluorescence and immuno-electron microscopy to determine the intracellular distribution of ligand-bound ER $\alpha$ and/or GFP-ER $\alpha$. Using fluorescence- and electron microscopy we demonstrate that both endogenous ER $\alpha$ and GFP-ER $\alpha$ form numerous nuclear focal accumulations upon addition of agonist, 17ק-estradiol (E2), and pure antagonists (selective estrogen regulator disruptor; SERD), ICI 182,780 or RU58,668, while in the presence of partial antagonists (selective estrogen regulator modulator; SERM), 4-hydroxytamoxifen (OHT) or RU39,411, diffuse nuclear staining persisted. Digitonin based cell fractionation analyses confirmed that endogenous ER $\alpha$ and GFP-ER $\alpha$ predominantly reside in the nuclear fraction. Overall ERo protein levels were reduced after estradiol treatment. In the presence of SERMs ER $\alpha$ was stabilized in the nuclear soluble fraction, while in the presence of SERDs protein levels decreased drastically and the remaining ER $\alpha$ was largely found in a nuclear insoluble fraction. mRNA levels of ESR1 were reduced compared to untreated cells in the presence of all ligands tested, including E2. E2 and SERDs induced ERa degradation occurred in distinct nuclear foci composed of ER $\alpha$ and the proteasome providing a simple explanation for ER $\alpha$ sequestration in the nucleus.

Conclusions: Our results indicate that chemical structure of ligands directly affect the nuclear fate and protein turnover of the estrogen receptor alpha independently of their impact on transcription. These findings provide a molecular basis for the selection of antiestrogen compounds issue from pharmacological studies aimed at improving treatment of breast cancer.
\end{abstract}

\section{Background}

The estrogen receptor alpha $(E R \alpha)$ is a member of the steroid nuclear receptor family. The gene coding for $E R \alpha(E S R 1)$ is regulated by seven different promoters that yield different transcripts, making it one of the most complex genes in the human genome [1]. Several splice variants have been described for estrogen receptor $\alpha$, but whether all these variants are expressed as functional proteins with biological functions is not clear $[2,3]$. In the classic pathway ER $\alpha$ undergoes a

\footnotetext{
* Correspondence: kerstin@biotoul.fr

† Contributed equally

'Université de Toulouse; UPS; Laboratoire de Biologie Moléculaire Eucaryote;

F-31062 Toulouse, France

Full list of author information is available at the end of the article
}

conformational change in the presence of estradiol, which leads to association with ER $\alpha$ target genes via direct binding to regulatory elements and modulation of their expression. This basic mechanism is influenced by other regulatory factors including alternate receptor isoforms, and the stoichiometry of coactivator and corepressor proteins. Coactivators have a common LXXLL motif [4] and after binding to the AF-2 domain of ER $\alpha$, facilitate recruitment of other factors [5]. Mutation analysis combined with crystallographic studies demonstrated that receptor-coactivator interactions are mediated through the ER $\alpha$ helix12 and the LXXLL motif of coactivators [6]. 4-hydroxytamoxifen (OHT) acts by blocking AF-2 activity so it is an antagonist in cells where AF-2 is dominant and a partial agonist 
where AF-1 is dominant [7]. Fulvestrant/ICI 182,780 (ICI) is known to block both, AF-2 and AF-1 activities.

Estrogens have a proliferative effect on various tissues, including the breast. Thus ER $\alpha$ plays a key role in mammary tumour development. In mammary cells, the effects of $17 \beta$-estradiol (E2) can be antagonized by compounds such as OHT, a tamoxifen metabolite that is a selective estrogen receptor modulator (SERM), and ICI, a selective estrogen receptor disruptor (SERD). OHT has partial agonist activity, depending on the tissue and response examined while ICI compounds are totally devoid of agonist activity in the models studied to date [8-10]. ER $\alpha-O H T$ complexes accumulate in nuclei and ICI treatment provokes rapid degradation of the ER $\alpha$ ICI complex by the nuclear proteasome $[11,12]$.

Intracellular levels of ER $\alpha$ are downregulated in the presence of E2, its cognate ligand, through the ubiquitin/proteasome (Ub/26S) pathway [10]. Polyubiquitination of liganded ER $\alpha$ is catalyzed by at least three enzymes: the ubiquitine-activating enzyme E1 activated ubiquitin is conjugated by E2 with lysine residues through an isopeptide bond by the E3 ubiquitin ligase. Polyubiquitinated ER $\alpha$ is then directed to the proteasome for degradation $[13,14]$. Most known ubiquitin attachment sites reside within the $\mathrm{C}$-terminus of the ER $\alpha$. Berry et al. recently also identified two receptor lysines, $\mathrm{K} 302$ and $\mathrm{K} 303$ in the hinge region of $\mathrm{ER} \alpha$ which are involved in E2 mediated and ICI induced $E R \alpha$ degradation in breast cancer cells [15]. Although ER-dependent transcription regulation and proteasome-mediated degradation of the ER $\alpha$ are linked [16], transcription per se is not required for ER $\alpha$ degradation and assembly of the transcription-initiation complex is sufficient to target ER $\alpha$ for degradation by the nuclear fraction of the proteasome [13]. Using immunocytochemical studies it was shown that ER $\alpha$ resides predominantly in the nucleus both in presence or absence of hormone [17]. Maruvada et al. [18] determined that a small proportion of transiently transfected GFP-ER $\alpha$ exists in the cytoplasm in the absence of hormone. They proposed that unbound $E R \alpha$ shuttles between the cytoplasm and nucleus in living cells. Estradiol and E2 antagonists affect ER $\alpha$ protein turnover rates and modulate transcription of ER $\alpha$ target genes $[19,20]$. It has been shown that E2 induced degradation of $E R \alpha$ is necessary for its ability to rapidly activate transcription [21]. Interestingly, two chemically different SERDs (ICI and RU58,668) competitively inhibit estradiol-mediated activation by ER $\alpha$ and induce rapid down-regulation of the receptor $[22,23]$. In contrast, in the presence of tamoxifen ER $\alpha$ protein levels increase, although the effect of OHT on transcription is similar to the one observed for SERD's in MCF-7 cells [19].
In the present study we determine the impact of different ligands on nucleocytoplasmic shuttling of ER $\alpha$ and examine the relationship between localization and proteolysis, two mechanisms involved in ER $\alpha$-mediated regulation in MCF-7 cells. To achieve this goal, we determined ER $\alpha$ protein concentration, subnuclear localization of $E R \alpha$ with relationship to the proteasome, and the level of ESR1 transcription upon treatment with various antiestrogens.

\section{Results}

\section{Ligands regulate $E R \alpha$ protein levels and transcription rates independently}

We first examined the kinetics of ER $\alpha$ protein turnover in MCF-7 cells following treatment with estradiol (E2), two SERMs (4-hydroxytamoxifen or OHT and RU39,411 or RU39) and two SERDs (ICI 182,780 or ICI and RU58,668 or RU58). It has been proposed that ligand dependent $E R \alpha$ regulation may result from the presence a long aliphatic side chain on steroid core. Thus in this study we selected RU39 and RU58 which are derivatives of $17 \beta$-estradiol but with different side chains. RU39 has a dimethyl-amino-ethoxy-phenyl side chain similar to the one in tamoxifen, while RU58 has a bulky hydrophobic side chain similar to the one in Fulvestrant (ICI) (Figure 1A). ER $\alpha$ protein levels in E2, ICI and RU58 treated MCF-7 cells rapidly decreased (Figure 1B). Time course experiments showed that $1 \mathrm{~h}$ after E2 induction, the detected amount of ER $\alpha$ protein accounted for only $40 \%$ of ER $\alpha$ levels before treatment; after $4 \mathrm{~h}, \mathrm{ER} \alpha$ levels were as low as $20 \%$ of the quantity of ER $\alpha$ present in untreated cells, and after $16 \mathrm{~h} E R \alpha$ protein remained at a level equivalent to the one observed $1 \mathrm{~h}$ after addition of E2. Treatment with SERDs (ICI and RU58) resulted in $>70 \%$ reduction of $\mathrm{ER} \alpha$ protein levels after $1 \mathrm{~h}, 4 \mathrm{~h}$ and even $16 \mathrm{~h}$ reaching 95\% after $1 \mathrm{~h}$ exposure to ICI (Figure 1B). Treatment of MCF-7 cells with OHT or RU39 (Figure 1B), two compounds classified as SERM, reduced from $40 \%$ to $50 \%$ of ER $\alpha$ protein levels at the initial $1 \mathrm{~h}$ time-point and about $20 \%$ after $16 \mathrm{~h}$ and $4 \mathrm{~h}$ treatment with OHT and RU39, respectively. In addition, ER $\alpha$ protein levels were almost equivalent to the ones detected in untreated cells after $4 \mathrm{~h}$ or $16 \mathrm{~h}$ culture in the presence of OHT or RU39. Hence, ER $\alpha$ protein levels are stabilized by SERMs.

To assess whether changes in protein levels reflect variations of $E R \alpha$ protein stability or of transcription rates of the ESR1 gene, we quantified ER $\alpha$ mRNA accumulated following $16 \mathrm{~h}$ treatment with the different compounds (Figure 1C). ESR1 mRNA expression was greatly reduced after treatment with $E R \alpha$ ligands. In the presence of E2, only $40 \%$ of ESR 1 mRNA could be recovered. Similarly, treatment with SERMs and SERDs 


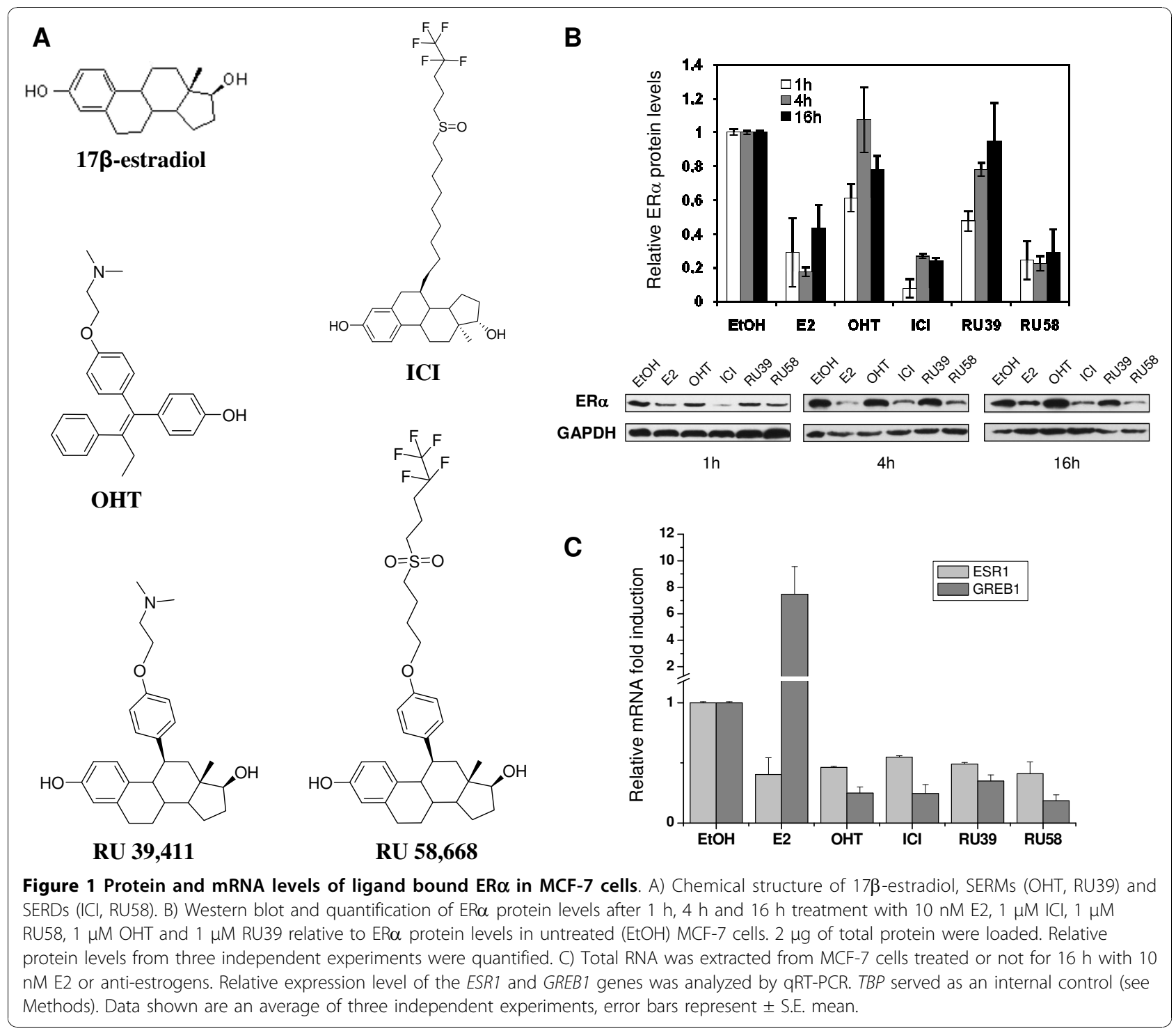

repressed ESR1 mRNA transcription by $45 \%-60 \%$ relative to untreated MCF-7 cells. Despite the fact that a reduction in ER $\alpha$ protein levels was readily detectable after $1 \mathrm{~h}$ and significant after $16 \mathrm{~h}$ (Figure 1B), we observed that E2 induced a 7 to 10 fold increase in mRNA levels of the ER $\alpha$-target gene GREB1 compared to mock treated cells (Figure 1C). GREB1 transcription was inhibited by SERMs and SERDs (> 40\% reduction compared to untreated cells; Figure 1C). These results were expected since E2 is known to activate this ER $\alpha$ target gene, while SERMs and SERDs are antiestrogens and thus repress GREB1 transcription in ER $\alpha$ positive mammary tumour cells [20].

Thus, in MCF-7 cells, variations in ER $\alpha$ protein levels do not necessarily correlate with ESR1 transcription in the presence of ligands. We note that the decrease in $\mathrm{ER} \alpha$ protein levels is more pronounced after treatment with SERDs than after addition of E2, while the effect of hormone and SERDs on ESR1 mRNA accumulation was comparable. These results indicate that reduction of $E R \alpha$ protein levels following treatment with SERDs cannot be solely attributed to decreased ESR1 mRNA levels. SERDs apparently act both on transcription of the ESR1 gene and on $E R \alpha$ protein turnover. In contrast, ER $\alpha$ protein levels appear stable after $16 \mathrm{~h}$ treatment with SERMs (data not shown) despite reduced ESR1 expression levels. This suggests that binding to SERMs stabilizes the ER $\alpha$.

\section{Ligands directly affect intracellular distribution and stability of ER $\alpha$}

SERMs and SERDs can be distinguished based on molecular mechanisms [9]. To unambiguously determine localization of the estrogen receptor and its intracellular 
trafficking in response to treatment with various ligands we established a MCF-7 cell line stably expressing GFP$\mathrm{ER} \alpha$ from a CMV promoter. It was previously shown that transiently expressed GFP-ER $\alpha$ is functional using an estrogen response element driven luciferase reporter gene [24]. Expression of GFP-ER $\alpha$ in MCF-7 cells did reportedly not alter cell cycle progression and GFP-ER $\alpha$ participated in estrogen target gene regulation similarly to endogenous ER $\alpha$ [25]. We tagged the N-terminus of the human ER $\alpha$ with the S65T variant of GFP for transfection and stable integration in MCF-7 cells. Several clones were recovered and screened for total GFP-ER $\alpha$ protein content after treatment with E2, OHT or ICI using fluorescence microscopy and western blots. Here, we selected a MCF-7 derived clone (SK19) expressing GFP-ER $\alpha$ in which changes in endogenous ER $\alpha$ protein levels in response to a $4 \mathrm{~h}$ treatment with E2, OHT and ICI were identical to the ones observed in MCF-7 cells (compare lanes labeled ER $\alpha$ in MCF-7 and SK19 cells in Figure 2A). In addition, mRNA expression levels of some ER $\alpha$ target genes, ESR1, TFF1/pS2, GREB1 and $P G R$, were verified in the selected clone SK19 and compared to gene expression levels in MCF-7 cells (Figure 2B). mRNA levels of the progesterone receptor gene $(P G R)$ and GREB1 increased rapidly after addition of $10 \mathrm{nM} \mathrm{E} 2$ to cells grown in steroid free medium to reach 2.2 to 2.8 fold (after $2 \mathrm{~h}$ ) for both genes, and after $16 \mathrm{~h}$ to reach from 3.8 to 4.6 fold for $P G R$ and 6.3 to 7.0 fold for GREB1 gene, in MCF-7 and SK19 cells respectively. TFF1 mRNA also accumulated after $16 \mathrm{~h}$ E2 treatment to reach 1.5 fold in both cell lines. As expected, $E S R 1$ transcription was reduced in the presence of E2. The RPLPO gene is not a target of ER $\alpha$ and its expression levels were insensitive to hormone addition. Expression levels of all tested genes were similar in SK19 and MCF-7 cells. Thus the presence of GFP-ER $\alpha$ does not alter hormone-responsiveness at the transcriptional level.

In SK19 cells, GFP-ER $\alpha$ protein accounted for $50 \%$ of total ER $\alpha$ (GFP-ER $\alpha$ and endogenous ER $\alpha$ ) in untreated cells. In the presence of E2 both GFP-ER $\alpha$ and endogenous ER $\alpha$ protein levels are reduced (Figure 2A). The CMV promoter being insensitive to E2 and antiestrogens, GFP-ER $\alpha$ protein levels are unlikely to be transcriptionally regulated. This observation together with the results shown in Figure 1 provides evidence that $\mathrm{ER} \alpha$ protein turnover is regulated directly by binding of the receptor to ligands and its subsequent degradation.

Previous studies have demonstrated that GFP-ER $\alpha$ resides predominantly in the nucleus in transiently transfected mammary tumour cell lines [24], Hela cells [26,27] and in MCF-7 cells expressing GFP-ER $\alpha$ from an inducible promoter [25]. These microscopy based observations largely contradict results based on cellular fractionation which suggest that large amounts of ER $\alpha$, in the absence or the presence of ligands, associate with the cytoplasmic fraction [19]. It has been proposed that the relative amount of cytoplasmic ER $\alpha$ is indicative of the mechanism of action of certain antiestrogens [19]. Commonly used cell fractionation protocols include a detergent based extraction step. Importantly, ER $\alpha$ and other nuclear receptors such as the glucocorticoid receptor (GR) are easily extracted from the nucleus in the presence of low concentrations of detergents such as NP40 (V. Marsaud and H. Richard-Foy, unpublished observations). As a consequence, apparent enrichment of ER $\alpha$ or GR in the cytoplasm likely results from the extraction protocol rather than a specific behavior of nuclear receptors. Here, we used a digitonin based cell fractionation protocol to determine the distribution of unbound and ligand-bound ER $\alpha$ and GFP-ER $\alpha$ in different cellular compartments (Figure 2C). Effectiveness of the fractionation protocol (for details see Methods) was confirmed using lamin A for the nuclear insoluble fractions, cytokeratin 18 for the nuclear and cytoplasmic fractions, and $\alpha$-tubulin for the cytoplasmic fraction (Figure 2C). Treatment of cells with E2 and various antiestrogens did not affect cellular distribution of these proteins. We found that endogenous ER $\alpha$ associates predominantly with the nuclear fraction in the SK19 cells. In untreated cells, the part of ER $\alpha$ retained in the cytoplasm corresponded to $\sim 20 \%$ of total endogenous ER $\alpha$ detected using the $\mathrm{HC}-20$ antibody (Figure 2C, lanes 1 and 13). Similarly, the bulk of GFP-ER $\alpha$, detected using either the HC-20 antibody or an antibody directed against GFP, was found in the nucleus. Following addition of E2, we note an overall decrease in ER $\alpha$ protein levels that could mainly be attributed to a reduction in nuclear ER $\alpha$ (Figure 2C, lanes 4-6). Treatment of SK19 cells with SERDs, ICI or RU58 leads to a decrease in overall ER $\alpha$ protein levels as shown for MCF-7 cells in Figure 1B. Notably, the remaining $E R \alpha$ was concentrated in the nuclear insoluble fraction which corresponded to $\geq 40 \%$ of total ER $\alpha$ in the presence of either ICI or RU58 (Figure 2C, lanes 12 and 21) suggesting that the nuclear soluble fraction was rapidly degraded. In contrast, we found that treatment with OHT and RU39 (Figure 2C, lanes 7-9 and 16-18) resulted in a cellular distribution similar to the one observed in untreated cells (Figure 2C, lanes 1-3) where at least $50 \%$ of $E R \alpha$ protein remained in a soluble nuclear compartment. Our cellular fractionation protocol is robust since the effects of various ligands are reproducible inside each category: OHT and RU39 induce the same effect on ER $\alpha$ protein distribution and this effect is distinct from the one of ICI and RU58. In addition, we show that occupation of different cellular compartments by GFP-ER $\alpha$ reflected the localization of endogenous $\mathrm{ER} \alpha$ as detected by fluorescence imaging (see below). 


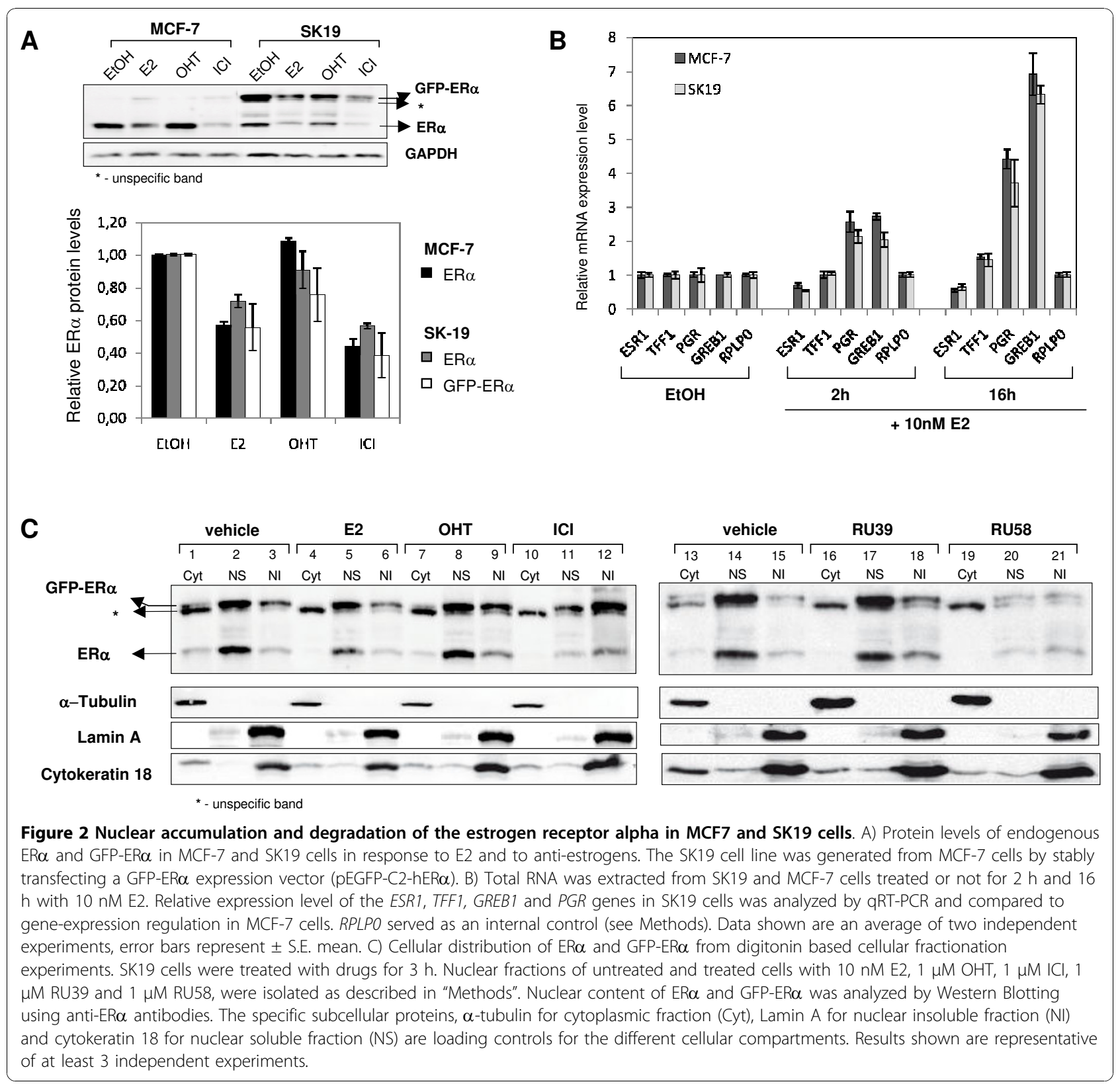

\section{Ligands induce specific intracellular relocalization of GFP-ER $\alpha$}

GFP-ER $\alpha$ can be visualized in SK19 cells using conventional wide-field microscopy. SK19 cells were cultured on conventional glass microscopy coverslips in phenolred free media for 3 days. Culture conditions were identical to conditions used for cell fractionation, immunoblotting or RNA extraction prior to RT-qPCR. Figure 3A shows representative images of SK19 cells treated or not with E2, SERMs and SERDs. We note that in the SK19 cell line GFP-ER $\alpha$ was excluded from the nucleoli, as previously observed for the cellular distribution of endogenous ER $\alpha$ in MCF-7 cells [28,29] and of transiently transfected GFP-ER $\alpha[24,26,30]$, under all conditions tested. Exposure times were identical for all conditions examined by fluorescence microscopy.

In untreated cells, ER $\alpha$ was uniformly distributed in the nucleus (compare GFP-ER $\alpha$ fluorescence (Figure $3 \mathrm{Ab})$, to the DAPI (4',6-diamidino-2-phenylindole) nuclear stain in Figure 3Aa). A linear scan across the entire field including cytoplasm and nucleus (Figure 3Ac) shows that the cytoplasmic GFP-ER $\alpha$ fluorescence was barely above background ( $15 \%$ of the maximum fluorescence intensity detected in the nucleus) which correlates with observations from cell fractionation experiments (Figure 2C, lane 1). In the presence of $\mathrm{E} 2$, 


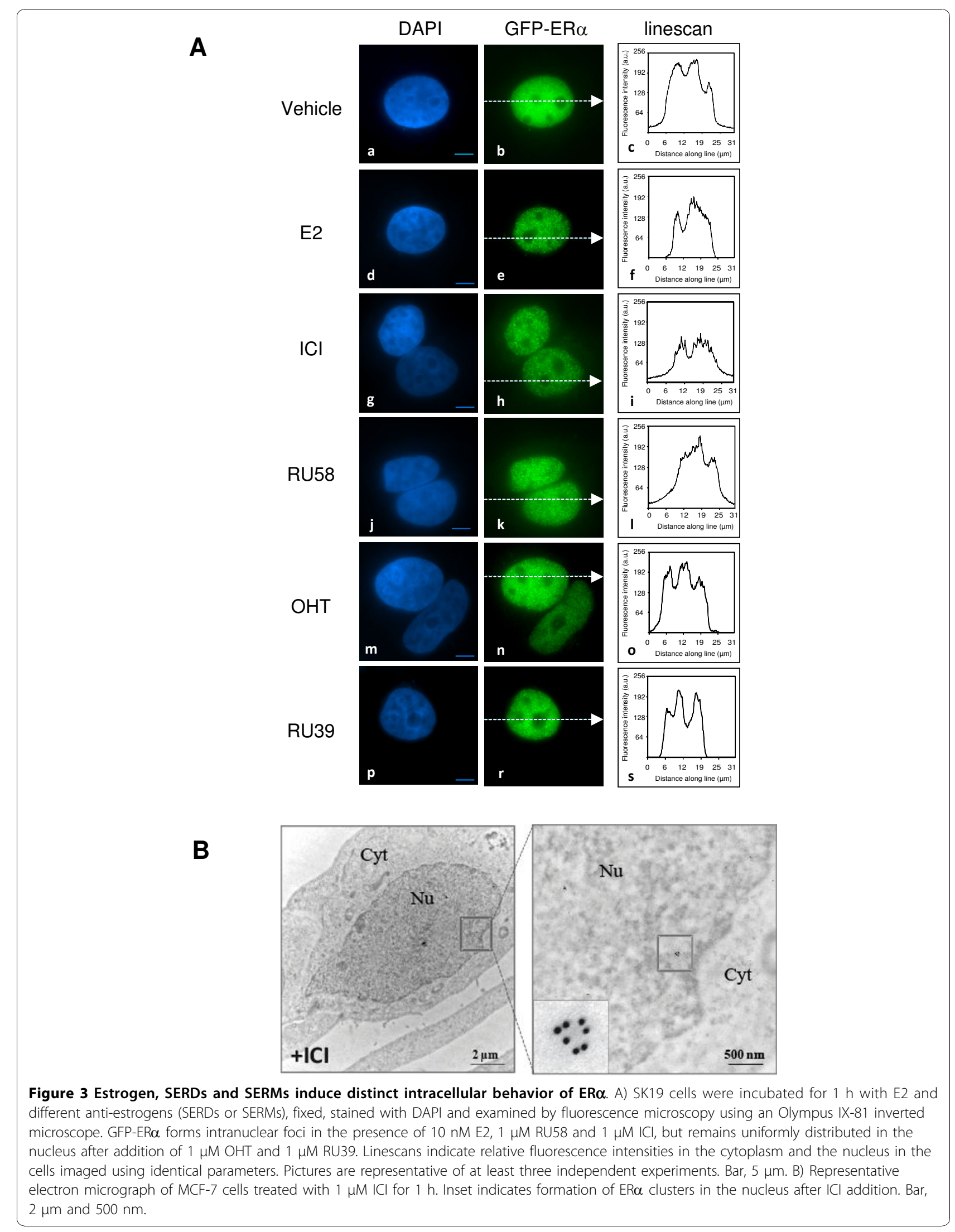


GFP-ER $\alpha$ rapidly relocalized to accumulate in numerous foci scattered throughout the nucleoplasm (Figure 3Ae). In E2 treated cells, no GFP-ER $\alpha$ fluorescence could be detected in the cytoplasm (see linescan Figure 3Af). In contrast, after $1 \mathrm{~h}$ treatment with SERMs, OHT or RU39, we did not observe any intranuclear reorganization of GFP-ER $\alpha$ compared to untreated cells. This observation also correlates with our fractionation experiments (Figure 2C, lanes 1-3 compare to lanes 7-8 and 16-18). GFP-ER $\alpha$ staining remained diffuse with fluorescence intensity comparable to mock cells (Figure $3 \mathrm{~A} \mathrm{~b}$, $\mathrm{n}, \mathrm{r}$ and corresponding linescans Figure $3 \mathrm{~A} \mathrm{c}, \mathrm{o}, \mathrm{s}$ ). However, again no cytoplasmic GFP-ER $\alpha$ could be detected.

The distribution of the intensity of the fluorescent signals was determined within nuclei excluding the nucleolus. The frequency of pixels with respect to their intensity allows to calculate a coefficient of variation (CV). In cells treated with SERMs the CV was comparable to the one in control cells while the CV was 2 to 3 fold higher in cells exposed to E2 or SERDs (Table 1). This quantitive measure strengthens our observation that ER $\alpha$ accumulates in intranuclear foci when bound to E2 or SERDs but not in the presence of SERMs.

Upon exposure to SERDs, both ICI and RU58, GFP$E R \alpha$ accumulated at numerous sites, reminiscent of the ones observed in the presence of E2 (Figure $3 \mathrm{~A} \mathrm{~h}, \mathrm{k}$ and 3Ae). We ascertained that the fluorescent foci detected in SK19 cells correspond to an accumulation of endogeneous ER $\alpha$ using immuno-electron microscopy of MCF7 cells. Several immunogold labeled ER $\alpha$ molecules were frequently detected within $\sim 100 \mathrm{~nm}$ distance from each other in $80 \mathrm{~nm}$ thin sections of E2 or ICI treated cells (Figure 3B).

In addition, in SK19 cells, the maximum fluorescence intensity measured after E2 and ICI treatments decreased by $20-40 \%$ as compared to untreated cells consistent with degradation of GFP-ER $\alpha$ (Figure 3Af and $3 \mathrm{Ai}$ compare to $3 \mathrm{Ac}$ ). The effects of ICI and RU58 were indistinguishable suggesting that both molecules operate via similar molecular mechanisms despite significant structural differences [19].

\begin{tabular}{|c|c|c|c|c|c|c|}
\hline $\begin{array}{l}\text { MCF-7 } \\
\text { cells }\end{array}$ & EtOH & E2 & $\mathrm{ICI}$ & RU58 & OHT & RU39 \\
\hline $\begin{array}{l}C V \\
( \pm S D)\end{array}$ & $\begin{array}{l}0,0248 \\
( \pm 0,008)\end{array}$ & $\begin{array}{l}0,061 \\
( \pm 0,013)\end{array}$ & $\begin{array}{l}0,0575 \\
( \pm 0,019)\end{array}$ & $\begin{array}{l}0,0622 \\
( \pm 0,019)\end{array}$ & $\begin{array}{l}0,0351 \\
( \pm 0,009)\end{array}$ & $\begin{array}{l}0,0425 \\
( \pm 0,013)\end{array}$ \\
\hline
\end{tabular}

Coefficients of variation of fluorescent intensities were measured after treatment with $10 \mathrm{nM} \mathrm{E2}$ and anti-estrogens as described in Methods. The distribution of the intensity of the fluorescent signals was determined within nuclei excluding the nucleolus in MCF-7 cells ( $n=15-20$ cells).

\section{Proteasome-dependent degradation of ER $\alpha$ bound to E2 or SERDs}

$E R \alpha$ is a short-lived protein (half-life of $>3 \mathrm{~h}$ for unbound $E R \alpha$ and $\sim 1-3 \mathrm{~h}$ for ligand-bound $E R \alpha$ ) $[10,31]$. ER $\alpha$ degradation occurs in presence of natural ligands (E2) or pure antiestrogens such as ICI in a proteasome dependent manner $[13,14,32]$.

The 26S proteasome is a large protein complex (1500$2000 \mathrm{kDa}$ ) present in the cytoplasm and nucleus of eukaryotic cells. The catalytic core of this multi-subunit complex, described as the $20 \mathrm{~S}$ proteasome, contains $\alpha$ and $\beta$ subunits [33]. We visualized GFP-ER $\alpha$ and the $20 \mathrm{~S}$ proteasome subunit $\alpha 2$ in SK19 cells. SK19 cells grown on glass coverslips and treated as described were fixed, permeabilized and subjected to indirect immunofluorescence using a monoclonal anti-20S proteasome subunit $\alpha 2$ primary antibody. Images acquired on an Olympus inverted wide-field microscope in $3 \mathrm{D}$ and subjected to deconvolution revealed punctuate nuclear staining of proteasome subunits throughout the nucleus (Figure 4A and 4D, center panels). We did not observe any cytoplasmic staining of this proteasome subunit under our culture conditions. In the presence of E2, GFP-ER $\alpha$ accumulated at numerous nuclear sites that colocalized at least partially with proteasome foci (Figure 4A panel $f$ ).

Next we used a double-immuno-nanogold labelling approach in MCF-7 cells to characterize the extent of $\mathrm{ER} / \alpha 2$ colocalization. Upon exposure to E2, at least four nuclear clusters per nuclear sections were detected. In the majority of clusters more than 3 gold particles for each protein were present (as indicated by circles in Figure 4B). Endogenous ER $\alpha$ (represented by $10 \mathrm{~nm}$ gold particles) colocalized with the $20 \mathrm{~S}$ proteasome subunit $\alpha 2$ (represented by $6 \mathrm{~nm}$ gold particles) in nuclear microdomains of about $100 \mathrm{~nm}$ in diameter (Figure 4B, inset).

We then determined the effect of LMB (Leptomycin B), an inhibitor of the nuclear export receptor CRM1, and of ALLN (acetyl-leucyl-leucyl-norleucinal), an inhibitor of the proteasome, on SERD-dependent degradation of ER $\alpha$ in SK19 cells. SK19 cells were pretreated with $10 \mathrm{nM}$ LMB or $100 \mu \mathrm{M}$ ALLN for $30 \mathrm{~min}$. Figure $4 C$ shows that LMB did not block E2, ICI or RU58 induced ER $\alpha$ degradation suggesting that SERD-bound $\mathrm{ER} \alpha$ is degraded in the nucleus. In the presence of E2, but not ICI or RU58, degradation was slightly less pronounced in cells pretreated with LMB suggesting that a fraction of E2 bound ER $\alpha$ is also degraded by the cytoplasmic proteasome. Furthermore, ALLN inhibited E2, ICI and RU58 induced degradation of ER $\alpha$ confirming that SERD-ER $\alpha$ complexes were degraded by the nuclear proteasome (Figure 4C, lanes 6, 9 and 12). Note that at the protein level, GFP-ER $\alpha$ is degraded to a 


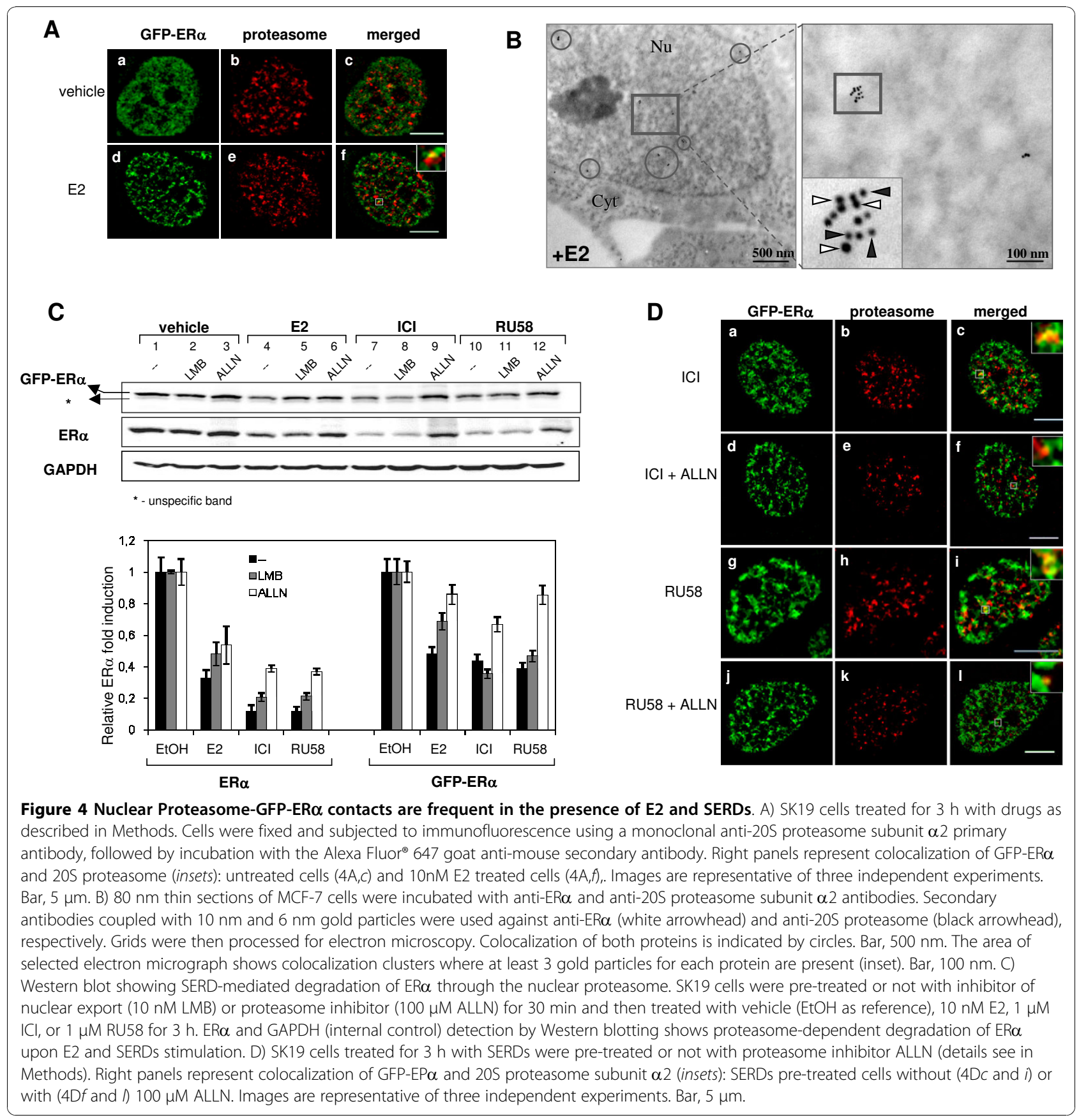

lesser extent than endogenous ER $\alpha$ which is likely to be a consequence of reduced transcription of ESR1 in the presence of E2 and SERDs. GFP-ER $\alpha$ transcription is under the control of a CMV promoter which insensitive to antiestrogens.

Finally, we investigated the distribution of GFP-ER $\alpha$ and the 20S proteasome subunit $\alpha 2$ in SK19 cells treated with ICI or RU58 (Figure 4D). GFP-ER $\alpha$ foci also significantly overlapped with accumulation sites of the
$20 \mathrm{~S}$ proteasome subunit $\alpha 2$ throughout the nucleus (Figure 4D, insets of panels $c$ and $i$ ). On average we observed larger and more frequent GFP-ER $\alpha$-proteasome complexes in the presence of SERDs than in the presence of E2 consistent with the fact that ER $\alpha$ is readily degraded when ER $\alpha$ is bound to SERDs. As a consequence of the ALLN treatment, contacts between GFP-ER $\alpha$ and proteasome foci were largely abolished (Figure 4D panels $f$ and $l$ ). 
Interestingly, in a few cells treated with either E2 or SERDs we observed a single very large site of accumulation of the $20 \mathrm{~S}$ proteasome $\alpha 2$ subunit (data not shown). These sites, also called clastosomes, were reported to colocalize with the c-jun and c-fos proteins [34], very unstable proteins with half lives of less than 90 min. In our cells, clastosomes did not colocalize with GFP-ER $\alpha$ foci which may indicate that E2 bound ER $\alpha$ is more stable than c-jun and/or c-fos proteins.

\section{Discussion}

The available quantity of ER $\alpha$ is a limiting factor in the response to ligands, estrogen and antiestrogens. Thus, determination of ER $\alpha$ cell content in patients is not only the first parameter for tumour classification, but also a powerful tool to predict response to hormonetherapies. ER $\alpha$ protein levels vary under physiological states, during tumor progression, and beyond therapy $[10,35,36]$. ER $\alpha$ protein levels are tightly regulated by the ubiquitin-proteasome pathway and loss of this control is associated with hormone insensitivity in breast cancer [37].

Most members of the nuclear receptor superfamily form focal accumulations within the nucleus in response to hormone [38]. Receptors undergo constant exchange between target sequences, multi-protein complexes including a variety of transcription factors, as well as subnuclear structures that are as yet poorly defined. The estrogen receptor alpha is found almost exclusively in the nucleus, both in hormone stimulated and untreated cells which makes it an exception among nuclear receptors which generally translocate from the cytoplasm into the nucleus upon hormone stimulation. Hager and colleagues [38] proposed that distribution of the ER $\alpha$ is dependent not only on localization signals, but also on the nature and composition of the associated macromolecular complexes. Formation of these complexes depends on the nature of the ligand bound to ER $\alpha$. Thus, as demonstrated here, ligands directly affect the nuclear fate of the receptor.

We created a MCF-7 cell line stably expressing GFPtagged human ER $\alpha$ to levels equivalent to endogenous $E R \alpha$, to determine the localization of ligand-bound GFP-ER $\alpha$ in mammary tumor cells. We demonstrate that few hours after treatment cellular localization of the ER $\alpha$ correlates with the nature of the ligand independently of its impact on transcription.

In the presence of E2 and SERMs which induce binding of ER $\alpha$ to target sequences and subsequent formation of macromolecular complexes, the small cytoplasmic fraction of E2 bound ER $\alpha$ rapidly translocated into the nucleus suggesting that DNA binding attracts cytoplasmic ER $\alpha$. In contrast, SERD bound cytoplasmic ER $\alpha$ was retained in the cytoplasm. SERDs induce a conformational change of ER $\alpha$ independently of its localization (cytoplasmic or nuclear) which leads to its rapid degradation. Our data also corroborate recent observations by Long and co-workers $[39,40]$ that ICI induces specific nuclear matrix interaction of protein-ER $\alpha$ complexes with cytokeratins 8 and 18 which mediate immobilization and turnover of ER $\alpha$. A non direct role of ER $\alpha$ in the cytoplasm has been proposed to play a role in acquired resistance to antiestrogens, in particular OHT [41]. Indeed, in OHT resistant cells, the $E R \alpha$ accumulated in the cytoplasm, suggesting that SERM stimulated ER $\alpha$ relocalization into the nucleus may be necessary for anti-hormone effectiveness (through the modulation of macromolecular complexes bound to the ER $\alpha$ ). An attractive possibility would thus reside in not only blocking indirect $E R \alpha$ functions which rely on MEK/ERK and PI3K pathways in SERM resistant tumors, but to increase $\mathrm{ER} \alpha$ translocation into the nucleus.

The crystal structure of ER $\alpha$ bound to different ligands has revealed a spectrum of conformational states $[9,42-44]$ that involve the repositioning of helix H12 of the receptor's ligand binding domain and formation the receptor's cofactor associating surfaces. It was proposed that the ligand binding cavity has a remarkable plasticity with a preferential binding mode for distal hydroxyl groups [43] showing similar orientations for distal side chains in $\alpha$ or $\beta$ positions of different ligands [43]. RU39 and RU58 are derivatives of $17 \beta$-estradiol but with different side chains. The shorter dimethyl-aminoethoxy-phenyl side chain is similar to the one in 4hydroxytamoxifen and likely to be easily accommodated by the cavity (Mazaheri et al in preparation). In contrast, RU58 has a bulky hydrophobic side chain similar to the one in fulvestrant (ICI) which hampers the folding of helix 12. Thus the molecular structure of ER $\alpha$ ligands alone indicates the potential for SERM or SERD -like activities of the compound (Mazaheri et al. in preparation).

Interestingly, E2 induced focal accumulations of ER $\alpha$ scattered throughout the nucleus in the presence of E2 and of SERDs (Figure 3A and 4A, D). In agreement with this observation, numerous ER $\alpha$-rich domains of about $100 \mathrm{~nm}$ are detectable following E2 stimulation (data not shown). It is well established that upon E2 addition, $\mathrm{ER} \alpha$ binds to promoter of ER $\alpha$-target genes [45]. Stimulated genes are found at numerous sites in the nucleus similarly to ER $\alpha$ protein [46]. Thus, we propose that the observed ER $\alpha$ rich nuclear clusters correspond to association of the receptor with chromatin structures of ER $\alpha$-responsive genes and the proteasome (Figure 3Ae and 4B) to ensure its own turnover while target genes are being transcribed. Similarly, SERD-bound $\mathrm{ER} \alpha$ also concentrated into nuclear foci (Figure 3Ah, $\mathrm{k}$ and 
3B) which frequently colocalize with the proteasome independently of DNA binding. This may explain why ligand bound ER $\alpha$ is less dynamic, and appears more strongly associated with nuclear matrix like structures [27].

Thus we propose a simple explanation reconciling all previous observations of ER $\alpha$ dynamics: ligands that allow ER $\alpha$ to bind its target sequence and to recruit macromolecular complexes induce ER $\alpha$ nuclear degradation or accumulation (E2 or SERMs); ligands that bind to ER $\alpha$ but do not lead to DNA binding due to conformational changes of the receptor do not induce relocalization of the receptor, but accelerate its degradation (SERDs); finally, ligands that induce association of ER $\alpha$ with the proteasome (E2 and SERDs) lead to focal accumulations and immobilize the ER $\alpha$. It is the association with the proteasome [47] and not active degradation by the proteasome that leads to ER $\alpha$ sequestration.

In the last 30 years clinical use of tamoxifen significantly improved survival rates of patients with hormone-dependent breast cancer types. However, resistance to this therapy arises frequently and numerous side effects exist. Since it is well established that total ER $\alpha$ content correlates with tumor growth in response to different ligands, it is crucial to characterize the exact mechanisms involved in anti-estrogen action and the impact of their structure on ER $\alpha$ conformation, cofactor recruitment and cellular compartmentalization. Knowledge of these parameters may allow to develop new compounds useful for patients resistant to existing therapies but may also benefit early diagnostics and treatment design.

\section{Conclusions}

In conclusion the results of this study indicate the impact of the estradiol and several SERM and SERD compounds, in particular RU39,411 and RU58,668, on nucleocytoplasmic shuttling and protein turnover of estrogen receptor alpha $(\mathrm{ER} \alpha)$ in human breast cancer cell lines. We found that ligands directly affect the nuclear fate and protein turnover of the receptor independently of their impact on transcription.

\section{Methods}

\section{Reagents}

$17 \beta$-estradiol (E2), 4-hydroxytamoxifen (OHT) and Leptomycine B (LMB) were purchased from Sigma-Aldrich (St. Louis, MO). ICI 182,780 (ICI) was purchased from Zeneca Pharmaceuticals. RU39,411 (RU39) and RU58,668 (RU58) were kindly provided by Dr. J.M. Renoir (Paris, France). Stock solutions of E2, OHT, ICI, RU39 and RU58 were prepared in ethanol. Stock solution of LMB was prepared in methanol. The solution of proteasome inhibitor acetyl-leucyl-leucyl-norleucinal (ALLN) was purchased from Calbiochem.
Rabbit polyclonal anti-ER $\alpha$ (HC-20), rabbit polyclonal anti-lamin A (H-102), rabbit polyclonal anti-cytokeratine 18 (H-80) were purchased from Santa Cruz Biotechnology, Inc. Mouse monoclonal anti-GAPDH (MAB374) was purchased from Chemicon International, mouse monoclonal anti-GFP from Roche, mouse monoclonal anti- $\alpha$-tubulin (clone DM1A) from Sigma-Aldrich. Mouse monoclonal anti-20S proteasome subunit $\alpha 2$ (clone MCP21) was gift from Dr. M.P. Bousquet (IPBS, Toulouse, France).

All cell culture products were obtained from Invitrogen.

\section{Cell culture and generation of stable GFP-ER $\alpha$ cell line}

Human breast cancer cell lines were maintained in Dulbecco's modified Eagle's medium F-12 (DMEM F-12) with Glutamax containing $50 \mu \mathrm{g} / \mathrm{ml}$ gentamicin, $1 \mathrm{mM}$ sodium pyruvate and $10 \%$ heat-inactivated fetal calf serum. All cells were grown at $37^{\circ} \mathrm{C}$ in a humidified atmosphere containing $5 \% \mathrm{CO}_{2}$. The stably transfected GFP-ER $\alpha$ reporter SK19 cell line was generated from ER $\alpha$-positive breast cancer MCF-7 cells (ATCC). 2nd passage cells were transfected with a GFP-ER $\alpha$ expression vector (pEGFP-C2-hER $\alpha$ ) using FuGENE ${ }^{\oplus} \mathrm{HB}$ Transfection Reagent (Roche Applied Science) and G418 resistant clones were selected at the concentration $1 \mathrm{mg} / \mathrm{ml}$. GFP-ER $\alpha$ expressing clones were isolated, ER $\alpha$ protein expression in response to estradiol and to antiestrogens was quantified using fluorescence microscopy and western blot. Expression of ER $\alpha$-regulated genes was tested by qRT-PCR and compared to gene-expression regulation in MCF-7 cells. The clone SK19 in which GFP-ER $\alpha$ behavior was comparable to endogenous $\mathrm{ER} \alpha$ was selected for further investigation.

To study the effects of estrogens and antiestrogens, cells were grown for 3 days in medium containing phenol red-free DMEM F-12 supplemented with 5\% charcoal-stripped fetal calf serum, without gentamicin and sodium pyruvate. Cells were subsequently treated or not with $10 \mathrm{nM}$ E2, $1 \mu \mathrm{M}$ ICI, $1 \mu \mathrm{M}$ OHT, $1 \mu \mathrm{M}$ RU39, $1 \mu$ M RU58 for the indicated times. To study ER $\alpha$ degradation by the proteasome, cells were pre-treated 30 min with $100 \mu \mathrm{M}$ ALLN, a proteasome inhibitor, or $10 \mathrm{nM}$ LMB, a nuclear export inhibitor.

\section{Cell extracts and Western blots}

MCF-7 cells grown in 6-well plates were treated as indicated, washed with ice-cold PBS and collected by centrifugation. Total cell lysates were prepared by resuspension of cells in $100 \mu$ lysis buffer (50 mM Tris $\mathrm{pH}=6.8,2 \%$ SDS, $5 \%$ glycerol, $2 \mathrm{mM}$ EDTA, $1.25 \%$ $\beta$-mercaptoethanol, $0.004 \%$ Bromophenol blue). The samples were boiled for $20 \mathrm{~min}$ at $95^{\circ} \mathrm{C}$ and cleared by centrifugation at $12000 \times g$ for $10 \mathrm{~min}$. Protein 
concentration was determined by an Amido Schwartz assay when the samples contained SDS. Samples were subjected to SDS-PAGE and proteins transferred onto nitrocellulose membranes. Western blot analysis was performed as previously described [48] using ER $\alpha$ and GAPDH antibodies and quantified using the TINA PCBase Software from FUJI.

\section{qRT-PCR experiments}

Total RNAs were extracted using TRIzol reagent (Invitrogen) following the manufacturer's protocol. 1-5 $\mu \mathrm{g}$ of total RNA was reverse transcribed in a final volume of $20 \mu \mathrm{l}$ using SuperScript ${ }^{\mathrm{TM}}$ III Reverse Transcriptase (Invitrogen). cDNA was stored at $-80^{\circ} \mathrm{C}$. All target transcripts were detected using quantitative RT-PCR (SYBRGreen SuperMix, Invitrogen) assays on a Mastercycler Realplex device (Eppendorf) using TBP or RPLPO genes as endogenous control for normalization of the data. The following primer pairs were used for amplification:

\section{TBP: 5'-CGGCTGTTTAACTTCGCTTTC-3' \\ 5'-CCAGCACACTCTTCTCAGCA-3' \\ ESR1: 5'-TGGAGATCTTCGACATGCTG-3' \\ 5'-TCCAGAGACTTCAGGGTGCT-3' \\ GREB1: 5'-GTGGTAGCCGAGTGGACAAT-3' \\ 5'AAACCCGTCTGTGGTACAGC-3' \\ RPLPO: (Fwd) 5'-TGGCAGCATCTACAACCCTGAA-} 3'

(Rev) 5'-ACACTGGCAACATTGCGGACA-3'

TFF1: (Fwd) 5'-CCCCTGGTGCTTCTATCCTAAT-3'

(Rev) 5'-CAGATCCCTGCAGAAGTGTCTA-3'

PGR: (Fwd) 5'-CTTAATCAACTAGGCGAGAG-3'

(Rev) 5'-AAGCTCATCCAAGAATACTG-3'

The results were analyzed using Mastercycler Realplex and qBASE software.

\section{Cell fractionation}

Three hours after incubation with ER $\alpha$ ligands, SK19 cells were washed with ice-cold PBS, scraped and centrifuged at $1,500 \mathrm{rpm}$ for $5 \mathrm{~min}$ at $4^{\circ} \mathrm{C}$. The pellets were resuspended in $150 \mu \mathrm{l}$ digitonin lysis buffer containing $1 \%$ digitonin and $1 \mathrm{mM}$ EDTA in PBS, immediately centrifuged at $13,000 \mathrm{rpm}$ for $20 \mathrm{~min}$ at $4^{\circ} \mathrm{C}$, to obtain the cytosolic fraction $(\mathrm{C})$. The pellets were resuspended in $150 \mu \mathrm{l}$ HEPES lysis buffer containing 1\% Triton X-100, $10 \%$ glycerol, $10 \mu \mathrm{g} / \mathrm{ml}$ leupeptin, $5 \mu \mathrm{g} / \mathrm{ml}$ aprotinin, $1 \mathrm{mM}$ PMSF, $1 \mathrm{mM} \mathrm{Na} \mathrm{VO}_{4}$ and $50 \mathrm{mM} \mathrm{NaF}$ in HEPES buffer (25 mM HEPES, 0.3 M NaCl, $1.5 \mathrm{mM}$ $\mathrm{MgCl}_{2}, 20 \mathrm{mM} \beta$-glycerol-phosphate, $2 \mathrm{mM}$ EDTA, $2 \mathrm{mM}$ EGTA and $1 \mathrm{mM}$ DTT), kept $15 \mathrm{~min}$ on ice and centrifuged at $13,000 \mathrm{rpm}$ for $15 \mathrm{~min}$ at $4^{\circ} \mathrm{C}$, to obtain the soluble nuclear fraction $(\mathrm{SN})$. The pellets from the previous step were resuspended in $100 \mu \mathrm{l}$ of a third buffer containing 95\% Laemmli buffer and 5\% $\beta$-mercaptoethanol and incubated $5 \mathrm{~min}$ on ice and boiled for
$20 \mathrm{~min}$ at $95^{\circ} \mathrm{C}$ to obtain the insoluble nuclear fraction (IN). The different fractions were stored at $-80^{\circ} \mathrm{C}$ until use. Protein concentrations were determined using the Bio-Rad Protein Assay (Bio-Rad).

\section{Immunofluorescence and Fluorescence microscopy}

For indirect immunofluorescence experiments, SK19 cells were grown for 3 days on coverslips in DMEM without phenol red, containing $5 \%$ charcoal-stripped fetal serum. After 3 days, cells were treated for $1 \mathrm{~h}$ with the following ligands: $10 \mathrm{nM} E 2,1 \mu \mathrm{M}$ ICI, $1 \mu \mathrm{M}$ OHT, $1 \mu \mathrm{M}$ RU39, $1 \mu \mathrm{M}$ RU58. Cells were then washed twice with PBS, fixed in $4 \%$ paraformaldehyde/PBS for $10 \mathrm{~min}$ at room temperature, subsequently permeabilized with $0.5 \%$ Triton X-100 in PBS for 15 min at room temperature, counterstained with DAPI (4,6-diamidino-2-phenylindole) and mounted on microscopy slides.

To study co-localization of ER $\alpha$ and proteasome by immunofluorescence, SK19 cells were grown for 3 days on coverslips in DMEM without phenol red, containing $5 \%$ charcoal-stripped fetal serum and next treated for $3 \mathrm{~h}$ with drugs as indicated above. To block proteasome-mediated ER $\alpha$ degradation, the cells were incubated 30 min with $100 \mu \mathrm{M}$ ALLN prior to treatment with ICI or RU58. Before immunostaining, cells were fixed in $4 \%$ paraformaldehyde/PBS for 30 minutes at room temperature, washed three times in PBS, quenched in $75 \mathrm{mM} \mathrm{NH}_{4} \mathrm{Cl}$ containing $20 \mathrm{mM}$ glycine and permeabilized with $0.5 \%$ Triton X-100 in PBS for 30 minutes. Next, cells were washed with PBS, blocked for $1 \mathrm{~h}$ at room temperature in 5\% dry milk in TBS-T (20 mM TRIS- $\mathrm{HCl}, 150 \mathrm{mM} \mathrm{NaCl}, 0.1 \%$ Tween 20, pH $=7.4$ ) and incubated overnight at $4^{\circ} \mathrm{C}$ with anti-20S proteasome antibody at a final concentration $2 \mu \mathrm{g} / \mathrm{ml}$ in $5 \%$ dry milk in TBS-T followed, after washing, by incubation with the Alexa Fluor 647 goat anti-mouse secondary antibody (1:1000, Invitrogen, Molecular Probes) for $90 \mathrm{~min}$ in the dark at room temperature. Finally, cells were washed with TBS-T, counterstained with DAPI and mounted on microscopy slides.

Cells were examined by fluorescence microscopy using an Olympus IX-81 microscope, equipped with a CoolSNAP HQ camera (Roper Scientific) and imaged through an Olympus oil-immersion objective 100x PLANAPO NA1.4. Images were recorded and deconvolved using Metamorph software (Universal Imaging). All images were processed for presentation using Adobe Photoshop 9.0.2.

\section{Electron microscopy}

MCF-7 cells were grown and treated as described above. For immune-electron microscopy cells were fixed with $4 \%$ paraformaldehyde in $\mathrm{Na}$ cacodylate buffer ( $\mathrm{pH} 7.4)$, dehydrated in a graded series of ethanol and embedded 
in acrylic resin (LRWhite). $80 \mathrm{~nm}$ ultrathin sections were mounted on Nickel grids, incubated with $2 \%$ BSA/ PBS and incubated overnight at $4{ }^{\circ} \mathrm{C}$ with a mixture of primary antibodies (anti -20S proteasome antibody at final concentration $2 \mu \mathrm{g} / \mathrm{ml}$ and anti-ER $\alpha$ antibody (dilution 1/500)) in 2\% BSA/PBS, washed 5 times for $5 \mathrm{mins}$ in $1 \% \mathrm{BSA} / \mathrm{PBS}$ and then labeled for $1 \mathrm{~h}$ with $6 \mathrm{~nm}$ goat anti-mouse and $10 \mathrm{~nm}$ goat anti-rabbit gold conjugated particles in 1\% BSA/PBS. Grids were finally washed 4 times for 5 mins in 1\% BSA/PBS, incubated for 15 mins in $1 \%$ glutaraldehyde/PBS, washed 2 times for 5 mins in PBS, 3 times in distilled water and dried at room temperature. The samples were visualized using $120 \mathrm{kV}$ Jeol electron microscope at $80 \mathrm{kV}$ and images were captured using a digital camera AMT.

\begin{abstract}
Acknowledgements
SK was supported by a postdoctoral fellowship from the Association pour la Recherche contre le Cancer (ARC). We acknowledge financial support from the Institut National du Cancer (INCa), Resisth network, ARC and La Ligue pour le Cancer. This work benefited of the assistance of the electron microscopy facility and the fluorescence microscopy equipment of the Toulouse RIO imaging platform.
\end{abstract}

\section{Author details}

${ }^{1}$ Université de Toulouse; UPS; Laboratoire de Biologie Moléculaire Eucaryote; F-31062 Toulouse, France. ${ }^{2}$ CNRS; LBME; F-31000 Toulouse, France.

\section{Authors' contributions}

SK created SK19 cell line, designed experiments, performed and analyzed immuno-electron and fluorescence microscopy data; MM designed experiments, performed and analyzed western blot and GRT-PCR experiments; SCS did the cell fractionation experiments; KB designed experiments, participated in data analysis and provided lab support; SK, MM and KB wrote the paper. All authors read and approved the final manuscript.

\section{Competing interests}

The authors declare that they have no competing interests.

Received: 12 March 2010 Accepted: 10 December 2010

Published: 10 December 2010

\section{References}

1. Kos M, Reid G, Denger S, Gannon F: Minireview: genomic organization of the human ERalpha gene promoter region. Mol Endocrinol 2001, 15(12):2057-2063.

2. Flouriot G, Brand H, Denger S, Metivier R, Kos M, Reid G, Sonntag-Buck V, Gannon F: Identification of a new isoform of the human estrogen receptor-alpha (hER-alpha) that is encoded by distinct transcripts and that is able to repress hER-alpha activation function 1. Embo J 2000, 19(17):4688-4700.

3. Poola I, Koduri S, Chatra S, Clarke R: Identification of twenty alternatively spliced estrogen receptor alpha mRNAs in breast cancer cell lines and tumors using splice targeted primer approach. I Steroid Biochem Mol Biol 2000, 72(5):249-258.

4. Kong EH, Pike AC, Hubbard RE: Structure and mechanism of the oestrogen receptor. Biochem Soc Trans 2003, 31(Pt 1):56-59.

5. McDonnell DP, Norris JD: Connections and Regulation of the Human Estrogen Receptor. Science 2002, 296:1642-1644.

6. Hall JM, McDonnell DP: Coregulators in Nuclear Estrogen Receptor Action: From Concept to Therapeutic Targeting. Mol Interv 2005, 5:343-357.

7. Pearce ST, Jordan VC: The biological role of estrogen receptors [alpha] and [beta] in cancer. Critical Reviews in Oncology/Hematology 2004, 50(1):3-22.
8. Jordan VC, Lieberman ME, Cormier E, Koch R, Bagley JR, Ruenitz PC: Structural requirements for the pharmacological activity of nonsteroidal antiestrogens in vitro. Mol Pharmacol 1984, 26(2):272-278.

9. Katzenellenbogen BS, Katzenellenbogen JA: Biomedicine. Defining the " $\mathrm{S}$ " in SERMs. Science 2002, 295(5564):2380-2381.

10. Alarid ET, Bakopoulos N, Solodin N: Proteasome-mediated proteolysis of estrogen receptor: a novel component in autologous down-regulation. Mol Endocrinol 1999, 13(9):1522-1534.

11. Giamarchi C, Solanas M, Chailleux C, Augereau P, Vignon F, Rochefort H, Richard-Foy H: Chromatin structure of the regulatory regions of pS2 and cathepsin D genes in hormone-dependent and -independent breast cancer cell lines. Oncogene 1999, 18(2):533-541.

12. Wijayaratne AL, McDonnell DP: The human estrogen receptor-alpha is a ubiquitinated protein whose stability is affected differentially by agonists, antagonists, and selective estrogen receptor modulators. $J$ Biol Chem 2001, 276(38):35684-35692.

13. Callige M, Kieffer I, Richard-Foy H: CSN5/Jab1 is involved in liganddependent degradation of estrogen receptor $\{a l p h a\}$ by the proteasome. Mol Cell Biol 2005, 25(11):4349-4358.

14. Nawaz Z, Lonard DM, Dennis AP, Smith CL, O'Malley BW: Proteasomedependent degradation of the human estrogen receptor. Proc Natl Acad Sci USA 1999, 96(5):1858-1862.

15. Berry NB, Fan M, Nephew KP: Estrogen receptor-alpha hinge-region lysines 302 and 303 regulate receptor degradation by the proteasome. Mol Endocrinol 2008, 22(7):1535-1551.

16. Lonard DM, Nawaz Z, Smith CL, O'Malley BW: The $26 S$ proteasome is required for estrogen receptor-alpha and coactivator turnover and for efficient estrogen receptor-alpha transactivation. Mol Cell 2000, 5(6):939-948.

17. Monje $\mathrm{P}$, Zanello S, Holick M, Boland R: Differential cellular localization of estrogen receptor [alpha] in uterine and mammary cells. Molecular and Cellular Endocrinology 2001, 181(1-2):117-129.

18. Maruvada P, Baumann CT, Hager GL, Yen PM: Dynamic Shuttling and Intranuclear Mobility of Nuclear Hormone Receptors. J Biol Chem 2003, 278:12425-12432.

19. Wittmann BM, Sherk A, McDonnell DP: Definition of functionally important mechanistic differences among selective estrogen receptor down-regulators. Cancer Res 2007, 67(19):9549-9560.

20. Frasor J, Stossi F, Danes JM, Komm B, Lyttle CR, Katzenellenbogen BS: Selective estrogen receptor modulators: discrimination of agonistic versus antagonistic activities by gene expression profiling in breast cancer cells. Cancer Res 2004, 64(4):1522-1533.

21. Jensen EV, Suzuki T, Numata M, Smith S, DeSombre ER: Estrogen-binding substances of target tissues. Steroids 1969, 13(4):417-427.

22. Buzdar AU, Robertson JF: Fulvestrant: pharmacologic profile versus existing endocrine agents for the treatment of breast cancer. Ann Pharmacother 2006, 40(9):1572-1583.

23. Bross PF, Baird A, Chen G, Jee JM, Lostritto RT, Morse DE, Rosario LA, Williams GM, Yang P, Rahman A, et al: Fulvestrant in postmenopausal women with advanced breast cancer. Clin Cancer Res 2003, 9(12):4309-4317.

24. Htun $H$, Holth LT, Walker D, Davie JR, Hager GL: Direct visualization of the human estrogen receptor alpha reveals a role for ligand in the nuclear distribution of the receptor. Mol Biol Cell 1999, 10(2):471-486.

25. Zhao H, Hart LL, Keller U, Holth LT, Davie JR: Characterization of stably transfected fusion protein GFP-estrogen receptor-alpha in MCF-7 human breast cancer cells. J Cell Biochem 2002, 86(2):365-375.

26. Stenoien DL, Mancini MG, Patel K, Allegretto EA, Smith CL, Mancini MA: Subnuclear trafficking of estrogen receptor-alpha and steroid receptor coactivator-1. Mol Endocrinol 2000, 14(4):518-534.

27. Stenoien DL, Patel K, Mancini MG, Dutertre M, Smith CL, O'Malley BW, Mancini MA: FRAP reveals that mobility of oestrogen receptor-alpha is ligand- and proteasome-dependent. Nat Cell Biol 2001, 3(1):15-23.

28. King WJ, Greene GL: Monoclonal antibodies localize oestrogen receptor in the nuclei of target cells. Nature 1984, 307(5953):745-747.

29. Welshons WV, Cormier EM, Wolf MF, Williams PO Jr, Jordan VC: Estrogen receptor distribution in enucleated breast cancer cell lines. Endocrinology 1988, 122(6):2379-2386.

30. Gushima M, Kawate H, Ohnaka K, Nomura M, Takayanagi R: Raloxifene induces nucleolar translocation of the estrogen receptor. Mol Cell Endocrinol 2010, 319(1-2):14-22. 
31. Eckert RL, Mullick A, Rorke EA, Katzenellenbogen BS: Estrogen receptor synthesis and turnover in MCF-7 breast cancer cells measured by a density shift technique. Endocrinology 1984, 114(2):629-637.

32. Marsaud V, Gougelet A, Maillard S, Renoir JM: Various phosphorylation pathways, depending on agonist and antagonist binding to endogenous estrogen receptor alpha (ERalpha), differentially affect ERalpha extractability, proteasome-mediated stability, and transcriptional activity in human breast cancer cells. Mol Endocrinol 2003, 17(10):2013-2027.

33. Brooks P, Fuertes $G$, Murray RZ, Bose $S$, Knecht E, Rechsteiner MC, Hendil KB, Tanaka K, Dyson J, Rivett J: Subcellular localization of proteasomes and their regulatory complexes in mammalian cells. Biochem J 2000, 346(Pt 1):155-161.

34. Lafarga M, Berciano MT, Pena E, Mayo I, Castano JG, Bohmann D, Rodrigues JP, Tavanez JP, Carmo-Fonseca M: Clastosome: a subtype of nuclear body enriched in 195 and $20 \mathrm{~S}$ proteasomes, ubiquitin, and protein substrates of proteasome. Mol Biol Cell 2002, 13(8):2771-2782.

35. Liedtke C, Broglio K, Moulder S, Hsu L, Kau SW, Symmans WF, Albarracin C, Meric-Bernstam F, Woodward W, Theriault RL, et al: Prognostic impact of discordance between triple-receptor measurements in primary and recurrent breast cancer. Ann Oncol 2009, 20(12):1953-1958.

36. Robertson JF, Llombart-Cussac A, Rolski J, Feltl D, Dewar J, Macpherson E, Lindemann J, Ellis MJ: Activity of fulvestrant $500 \mathrm{mg}$ versus anastrozole 1 $\mathrm{mg}$ as first-line treatment for advanced breast cancer: results from the FIRST study. J Clin Oncol 2009, 27(27):4530-4535.

37. Harrell JC, Dye WW, Harvell DM, Pinto M, Jedlicka P, Sartorius CA, Horwitz KB: Estrogen insensitivity in a model of estrogen receptor positive breast cancer lymph node metastasis. Cancer Res 2007, 67(21):10582-10591.

38. Hager GL, Lim CS, Elbi C, Baumann CT: Trafficking of nuclear receptors in living cells. J Steroid Biochem Mol Biol 2000, 74(5):249-254.

39. Long X, Nephew KP: Fulvestrant (ICI 182,780)-dependent interacting proteins mediate immobilization and degradation of estrogen receptoralpha. J Biol Chem 2006, 281(14):9607-9615.

40. Long X, Fan M, Nephew KP: Estrogen receptor-alpha-interacting cytokeratins potentiate the antiestrogenic activity of fulvestrant. Cancer Biol Ther 2010, 9(5).

41. Fan P, Wang J, Santen RJ, Yue W: Long-term treatment with tamoxifen facilitates translocation of estrogen receptor alpha out of the nucleus and enhances its interaction with EGFR in MCF-7 breast cancer cells. Cancer Res 2007, 67(3):1352-1360.

42. Brzozowski AM, Pike AC, Dauter Z, Hubbard RE, Bonn T, Engstrom O, Ohman L, Greene GL, Gustafsson JA, Carlquist M: Molecular basis of agonism and antagonism in the oestrogen receptor. Nature 1997, 389(6652):753-758

43. Pike AC, Brzozowski AM, Walton J, Hubbard RE, Thorsell AG, Li YL, Gustafsson JA, Carlquist M: Structural insights into the mode of action of a pure antiestrogen. Structure 2001, 9(2):145-153.

44. Shiau AK, Barstad D, Loria PM, Cheng L, Kushner PJ, Agard DA, Greene GL: The structural basis of estrogen receptor/coactivator recognition and the antagonism of this interaction by tamoxifen. Cell 1998, 95(7):927-937.

45. Fullwood MJ, Liu MH, Pan YF, Liu J, Xu H, Bin Mohamed Y, Orlov YL, Velkov S, Ho A, Mei PH: An oestrogen-receptor-alpha-bound human chromatin interactome. Nature 2009, 462(7269):58-64.

46. Kocanova S, Kerr EA, Rafique S, Boyle S, Katz E, Caze-Subra S, Bickmore WA, Bystricky K: Activation of estrogen-responsive genes does not require their nuclear co-localization. PLoS Genet 2010, 6(4):e1000922.

47. Sato K, Rajendra E, Ohta T: The UPS: a promising target for breast cancer treatment. BMC Biochem 2008, 9(Suppl 1):S2.

48. Giamarchi C, Chailleux C, Callige M, Rochaix P, Trouche D, Richard-Foy H: Two antiestrogens affect differently chromatin remodeling of trefoil factor 1 (pS2) gene and the fate of estrogen receptor in MCF7 cells. Biochim Biophys Acta 2002, 1578(1-3):12-20.

doi:10.1186/1471-2121-11-98

Cite this article as: Kocanova et al:: Ligands specify estrogen receptor alpha nuclear localization and degradation. BMC Cell Biology 2010 11:98.

\section{Submit your next manuscript to BioMed Central and take full advantage of:}

- Convenient online submission

- Thorough peer review

- No space constraints or color figure charges

- Immediate publication on acceptance

- Inclusion in PubMed, CAS, Scopus and Google Scholar

- Research which is freely available for redistribution

Submit your manuscript at www.biomedcentral.com/submit 